\title{
POLA ASUH ORANG TUA TERHADAP SOSIOEMOSIONAL ANAK TUNARUNGU USIA SEKOLAH
}

\author{
Farial Nurhayati ${ }^{1}$, Ningning Sri Ningsih ${ }^{2}$ \\ ${ }^{1,2}$ Program Studi Keperawatan Bogor Poltekkes Kemenkes Bandung \\ Email: farialn@yahoo.com
}

\begin{abstract}
Parenting Style to Social Emotion of Deaf Children. WHO said the number of children with special needs in Indonesia was around 7\% of the total number of children aged 0-18 years, or amounting to 6.23 million, in 2007. The delay in the development of language skills were resulted in low academic achievement. Parenting is interaction between children and parents in terms of educating, guiding, and discipline, also protecting the child to reach maturity in accordance with the norms that exist in society. This study was to determine the relationship between parenting style with deaf children's socioemotional. It was cross sectional research methods with 42 respondents. Respondents were parents of deaf children at extraordinary school in the city of Bogor. Statistical test results were obtained by $p$-value $=0.183$, it can be concluded there was no significant association between parenting style with socioemotional deaf children. Arman et all (2008) said socioemotional factors that affected a child were the following individual risk factors, such as child temperament, age, gender, developmental delays, serious health problems, family factors and environmental factors.
\end{abstract}

Keywords: Parenting style, Socioemotional, Deaf children

\begin{abstract}
Abstrak: Pola Asuh Orang Tua terhadap Sosioemosional Anak Tunarungu Usia Sekolah. Menurut WHO jumlah anak berkebutuhan khusus di Indonesia adalah sekitar 7\% dari total jumlah anak usia 0-18 tahun atau sebesar 6.230.000 pada tahun 2007. Banyak yang mencatat adanya keterlambatan pada perkembangan keterampilan berbahasa sehingga mengakibatkan pencapaian prestasi akademik yang rendah. Pola asuh merupakan interaksi anak dan orang tua dalam hal mendidik, membimbing, dan mendisplinkan serta melindungi anak untuk mencapai kedewasaan sesuai dengan norma-norma yang ada dalam masyarakat. Tujuan penelitian adalah untuk mengetahui hubungan antara pola asuh orang tua dengan sosio emosional anak tunarungu. Desain penelitian ini menggunakan metode penelitian cross sectional dengan jumlah responden 42 responden orang tuaanak tuna rungu di SLB Kota Bogor. Hasil uji statistik diperoleh nilai $p=0,183$ maka dapat disimpulkan tidak ada hubungan signifikan antara pola asuh dengan sosioemosional anak tuna rungu. Faktor yang memengaruhi sosioemosional anak menurut Artman et al (2008) adalah sebagai berikut faktor risiko individu, seperti tempramen anak, usia, jenis kelamin, keterlambatan perkembangan, masalah kesehatan serius, faktor keluarga dan faktor lingkungan.
\end{abstract}

Kata kunci: Pola asuh, Sosioemosional, Anak tunarungu

Data dari Direktorat Pembinaan Sekolah Luar Biasa Kementerian Pendidikan Nasional 2009, menunjukkan bahwa ada 70.501 ABK yang sekolah di Taman Kanak-kanak sampai Sekolah Menengah Pertama dan. Siswa ABK yang terdaftar di SLB jenjang TK hingga SMA pada tahun 2009 adalah tunanetra 1.105 orang, tunarungu/tunawicara 5.610 orang, tunagrahita 4.253 orang, tunadaksa 229 orang, tunalaras 487 orang, autis 638 orang, dan tunaganda 171 orang. Sedangkan data Kementerian Sosial tahun 2012 menyebutkan bahwa siswa $\mathrm{ABK}$ dari jenjang SD hingga SMA berjumlah 542.722 dengan siswa SD berjumlah 386.753, SMP berjumlah 91.196 siswa, dan SMA berjumlah 64.773 siswa (Kemenkes , 2010).
Tunarungu adalah istilah umum yang digunakan untuk menyebut kondisi seseorang yang mengalami gangguan dalam indera pendengaran (Smart, 2014). Banyak yang mencatat adanya keterlambatan pada perkembangan keterampilan berbahasa sehingga mengakibatkan pencapaian prestasi akademik yang buruk (Edwards, 2015).

Orang tua adalah lingkungan pertama dan utama dalam kehidupan anak, termasuk perkembangan intelektual anak. Walaupun anak usia sekolah sudah mulai mempunyai lingkungan lain selain lingkungan keluarga. Orang tua memiliki cara dan pola tersendiri dalam mengasuh dan membimbing anak. Selama proses tumbuh kembang anak, pola asuh orangtua akan 
sangat menentukan kepribadian anak yang akan terbentuk nantinya. Menurut Baumrind (1997) dalam Antonopoulou (2012) menjelaskan jenis pola asuh orangtua yang diberikan pada anak meliputi pola asuh Otoriter, Permisif dan Demokratis. Hasil penelitian Rahmanpour, et al (2014) yang membandingkan penerapan pola asuh pada anak normal dengan anak tuna rungu, menyatakan bahwa tidak ada perbedaan pola asuh orang tua pada anak tuna rungu dengan anak normal dimana pola asuh yang diterapkan meliputi pola asuh otoriter, permisif dan demokratis.

Pengasuhan sosioemosional adalah upaya yang dilakukan agar anak sukses dalam kehidupan bersama orang lain. Emosional dapat berkembang dengan baik sebagai diri sendiri maupun dalam lingkungan sosial. Anak belajar untuk berempati, tenggang rasa, menghargai dan menghormati orang lain (Berg, 2011).

Beberapa penelitian menunjukkan adanya risiko tinggi pada anak tunarungu mengalami masalah kesehatan mental. Faktor lingkungan yang berkontribusi pada hal ini diantaranya adalah kurangnya akses komunikasi bernahasa, sedikitnya kesempatan anak tunarungu berinteraksi dengan temannya, isolasi serta adanya bullying (Edwards, 2015). Anak dengan kebutuhan khusus seperti anak dengan tunarungu membutuhkan lingkungan yang kondusif untuk tumbuh kembangnya terutama untuk kebutuhan sosioemosionalnya. Orang tua melalui pola asuhnya memegang peranan penting dalam tumbuh kembang anak dengan tunarungu.

$$
\text { Menurut Baumrind }
$$

mengungkapkan tentang dampak masing-masing pola asuh orangtua terhadap sosioemosional anak dimana pola asuh otoriter memberikan dampak sosioemosional berupa bullying, kurang mampu berteman, ketakutan, marah, menyendiri, hilangnya kekhawatiran akan tugasnya, sedangkan pola asuh orangtua permisif adalah kurang mampu mengendalikan diri, bentindak sesuai keinginannya, menyendiri kadang tidak bersahabat, pengendalian diri kurang dan pola asuh demokratis meliputi anak aktif dilingkungannya, tegas terhadap temannya, empati dan pengertian, dapat mengendalikan diri serta sangat percaya diri.

Peneliti memilih menggunakan kuesioner

SDQ (Strengths and Difficulties Questionnaire) untuk mengukur sosioemosional anak. Hintermair (2007) mengemukakan bahwa SDQ telah digunakan dalam studi penelitian, alat ukur ini berguna untuk mendiagnosis masalah sosioemosional pada anak tunarungu.
Pengukuran pola asuh dapat dilakukan dengan menggunakan kuesioner. Kuesioner yang dapat digunakan dalam mengukur pola asuh orang tua tersebut adalah Alabama Parenting Questionnaire (Frick, 1991) yang telah dimodifikasi oleh peneliti.

\section{METODE PENELITIAN}

Dalam rancangan penelitian ini menggunakan metode deskriptif dengan pendekatan cross sectional. Sampel penelitian menggunakan quota sampling dari dua sekolah Luar Biasa di Kota Bogor. Jumlah orang tua siswa/siswi yang menjadi responden yaitu 42 orang. Pengumpulan data dilakukan dengan kuesioner. Penelitian ini dilakukan dengan langkah-langkah mengumpulkan data melalui pernyataan terstruktur atau kuesioner penelitian, klasifikasi, pengolahan atau analisa data, membuat kesimpulan dan laporan.

\section{HASIL}

\begin{tabular}{llrr} 
Tabel 1. Distribusi & \multicolumn{1}{c}{$\begin{array}{c}\text { Frekuensi } \\
\text { Berdasarkan Karakteristik Responden }\end{array}$} \\
\hline \multicolumn{1}{c}{ Karakteristik } & Sub karakteristik & Responden & \% \\
\hline Jenis kelamin anak & Laki-laki & 24 & 57,1 \\
& Perempuan & 18 & 42,9 \\
\hline Tingkat pendidikan & SD & 2 & 4.8 \\
orang tua & SMP & 13 & 31,0 \\
& SMA & 20 & 47,6 \\
& PT & 7 & 16,7 \\
\hline Pekerjaan orang tua & Bekerja & 25 & 59,5 \\
& Tidak bekerja & 17 & 40,5 \\
\hline Pengalaman & & & \\
mengasuh anak & Pengalaman & 1 & 2,3 \\
tunarungu & Tidak pengalaman & 41 & 97,7 \\
\hline
\end{tabular}

Distribusi jenis kelamin anak tuna rungu terbanyak adalah laki-laki yaitu 24 orang $(57,1 \%)$. Sedangkan yang berjenis kelamin perempuan sebanyak 18 orang $(42,9 \%)$.

Distribusi tingkat pendidikan responden terbanyak adalah SMA yaitu 20 orang $(47,6 \%)$ dan yang terkecil adalah pendidikan SD yaitu 2 orang $(4,8 \%)$.

Distribusi pekerjaan orang tua (Ibu) terbanyak adalah bekerja yaitu 25 orang $(59,5 \%)$, sedangkan yang tidak bekerja yaitu 17 orang $(40,5 \%)$. pengalaman mengasuh anak tunarungu yaitu sebagian besar yaitu 41 orang $(2,3 \%)$ tidak memiliki pengalaman mengasuh anak tunarungu. 
Tabel 2. Distribusi Frekuensi Responden berdasarkan Usia Anak dan Usia Orang Tua

\begin{tabular}{lccrc}
\hline \multicolumn{1}{c}{ Variabel } & Mean & SD & $\begin{array}{c}\text { Min- } \\
\text { Maks }\end{array}$ & $\begin{array}{c}\mathbf{9 5 \%} \\
\text { CI }\end{array}$ \\
\hline Usia anak & 10,45 & 1,98 & $6-12$ & $\begin{array}{c}9,84- \\
11,07\end{array}$ \\
\hline Usia orang tua & 39,25 & 5,18 & $29-49$ & $\begin{array}{c}37,62- \\
40,85\end{array}$ \\
\hline
\end{tabular}

Hasil analisis didapatkan rata-rata umur anak tuna rungu adalah 10,45 tahun (95\% CI: 9,84-11,07), dengan standar deviasi 1,98 tahun. Umur termuda 6 tahun dan umur tertua 12 tahun. Dari hasil estimasi interval dapat disimpulkan bahwa $95 \%$ diyakini bahwa rata-rata umur anak tuna rungu adalah diantara 9,84 sampai dengan 11,07 tahun.

Rata-rata umur orang tua adalah 39,25 tahun (95\% CI: 37,62-40,85), dengan standar deviasi 5,18 tahun. Umur termuda 29 tahun dan umur tertua 49 tahun. Dari hasil estimasi interval dapat disimpulkan bahwa 95\% diyakini bahwa rata-rata umur orang tua adalah diantara 37,62 sampai dengan 40,85 tahun.
Tabel 3. Distribusi Frekuensi Responden berdasarkan Pola Asuh Orang Tua dan Sosioemosional anak Tuna Rungu

\begin{tabular}{llrr}
\hline \multicolumn{1}{c}{ Variabel } & n & \% \\
\hline Pola Asuh & Demokratis & 39 & 92,9 \\
& Permisive & 2 & 4,8 \\
& Otoriter & 1 & 2,4 \\
\hline Sosioemosional & Normal & 9 & 21,4 \\
anak tunarungu & Rata-rata & 7 & 16,7 \\
& Abnormal & 26 & 61,9 \\
\hline
\end{tabular}

Distribusi pola asuh orang tua terbanyak adalah demokratis yaitu 39 orang $(92,9 \%)$. Sedangkan yang berjenis pola asuh permissive dan otoriter hampir sama banyak yaitu permissive 2 orang $(4,8 \%)$ dan pola asuh otoriter 1 orang $(2,4 \%)$.

Distribusi kondisi sosioemosional anak tuna rungu terbanyak adalah abnormal yaitu 26 orang $(61,9 \%)$. Sedangkan yang sosioemosional normal dan rata-rata hampir sama yaitu sosioemosional normal 9 orang $(21,4 \%)$ dan sosioemosional rata-rata 7 orang $(16,7 \%)$.

\begin{tabular}{|c|c|c|c|c|c|c|c|c|c|}
\hline \multirow[t]{3}{*}{ Pola Asuh } & \multicolumn{6}{|c|}{ Sosioemosional Anak Tunarungu usia Sekolah } & \multirow{2}{*}{\multicolumn{2}{|c|}{ Total }} & \multirow{3}{*}{$p$-value } \\
\hline & \multicolumn{2}{|c|}{ Normal } & \multicolumn{2}{|c|}{ Rata-rata } & \multicolumn{2}{|c|}{ Abnormal } & & & \\
\hline & $\mathbf{n}$ & $\%$ & $\mathbf{n}$ & $\%$ & $\mathbf{n}$ & $\%$ & $\mathbf{n}$ & $\%$ & \\
\hline Demokratis & 8 & 19,0 & 6 & 14,3 & 25 & 59,5 & 39 & 92,8 & \multirow{4}{*}{0,183} \\
\hline Permisif & 1 & 2,4 & 0 & 0 & 1 & 2,4 & 2 & 4,8 & \\
\hline Otoriter & 0 & 0 & 1 & 2,4 & 0 & 0 & 1 & 2,4 & \\
\hline Jumah & 9 & 21,4 & 7 & 16,7 & 26 & 61,9 & 42 & 100 & \\
\hline
\end{tabular}

Hasil analisis hubungan antara pola asuh orang tua dengan sosio emosional anak tuna rungu diperoleh bahwa ada sebanyak $8(19,0 \%)$ orang tua dengan pola asuh demokratis memiliki anak tuna rungu dengan sosioemosional normal. Ada sebanyak $1(2,4 \%)$ orang tua dengan pola asuh permisif mmeiliki anak tuna rungu dengan sosioemosional normal. sedangkan orang tua dengan pola asuh otoriter tidak ada yang memiliki anak dengan sosioemosional normal $(0 \%)$. hasil uji statistik diperoleh nilai $p=0,183$ maka dapat disimpulkan tidak ada perbedaan proporsi kejadian anak dengan sosioemosional normal antara orang tua dengan pola asuh demokratis, permisif dan otoriter (tidak ada hubungan signifikan antara pola asuh dengan sosioemosional anak tuna rungu).

\section{PEMBAHASAN}

Penelitian yang dilakukan oleh Maria S. Poulou pada tahun 2010 mengenai "Emotional Intelligence dan Kemampuan Sosioemosional" menunjukkan perbedaan yang signifikan pada kemampuan sosioemosional dan perilaku antara laki-laki dan perempuan.

Pada umumnya orangtua akan mengatahui tingkat perkembangan anak dan bagaimana pola asuh yang sesuai dengan perkembangan anak terutama anak dengan berkutuhan khusus. Hasil penelitian Galih (2009), menunjukan bahwa orangtua yang berpendidikan tinggi cenderung memilih pola asuh demokratis. Hasil penelitian Herlina (2013) menunjukan bahwa pendidikan orangtua terbanyak adalah rendah dan pola asuh yang paling dominan diterapkan pada anak adalah pola asuh permisif.

Hasil penelitian menunjukan bahwa pola asuh terbanyak yang diterapkan orangtua pada anak tunarungu usia sekolah adalah Demokratis 
yaitu 39 orang $(92 \%)$. Hasil penelitian ini menunjukan bahwa orangtua memberikan dukungan emosional dengan struktur dan bimbingan pada anak untuk mandiri tetapi tetap menerapkan berbagai batasan yang akan mengontrol perilaku mereka.

Menurut Edwards (2006) terdapat beberapa faktor yang mempengaruhi pola asuh orangtua di rumah yaitu tingkat pendidikan dan pengetahuan, pengalaman, lingkungan, budaya, stress ibu, hubungan suami istri dan umur ibu.

Hasil penelitian Antonopoulou (2012) menyatakan bahwa tidak ada perbedaan yang pola asuh yang diterapkan pada anak tunarungu tetapi yang paling dominan adalah pola asuh demokratis dimana orangtua lebih bertanggungjawab terhadap perasaan anak dan dukungan yang aman bagi anak dengan tunarungu.

Hasil penelitian Emanora, Muflikhati dan Alfiasari, (2012) dimana pengukuran sosioemosional berdasarkan Kategori dan hasilnya terbanyak kategori sedang yaitu 35 orang $(70 \%)$, hal ini menunjukkan bahwa perkembangan sosioemosional anak usia sekolah belum optimal. Perkembangan sosioemosional adalah kemampuan anak untuk mengerti perasaan orang lain, mengontrol perasaan dan tingkah lakunya, serta dapat berhubungan dengan teman sebaya. Kemampuan dasar yang dibutuhkan anak, seperti kerjasama, menuruti bimbingan, menerapkan kontrol diri, dan memperhatikan, akan tercapai jika mereka memiliki kemampuan sosioemosional (Summer, 2009).

Pola asuh demokratis merupakan tipe orangtua yang hangat, mendukung, memberikan perhatian serta menggali sesuatu yang menjadi cita-cita atau kesenangan anak. Orangtua menuntut kematangan pada anaknya dan dalam merawat anak orangtua menggunakan komunikasi dua arah, menjelaskan perilaku anak dan mengajarkan tidak tergantung atau mandiri meskipun anak mempunyai keterbatasan (tunarungu), memberi batasan serta mengontrol perilaku anak, menghidari hukuman atau kritikan yang tidak rasional maupun ekspresi negatif secara verbal atau non verbal. (Antonopoulou, dkk, 2012).

Beberapa faktor yang mempengaruhi pola asuh anak meliputi tingkat pendidikan dan pengalaman orangtua sangat berpengaruh dalam mengasuh anak, lingkungan, budaya, stres ibu, hubungan suami istri yang kurang harmonis, aktifitas ibu dan umur ibu (Edward, 2006).

Perkembangan emosional anak merupakan interaksi yang dinamis antara orang tua dan anak serta lingkungan tempat tinggal. Salah satu aspek dari lingkungan adalah gaya pola asuh orang tua, yang mencerminkan kondisi emosional orang tua sebagai keluarga. Ada tiga dimensi dari pola asuh pada perkembangan anak, yaitu kasih sayang, kontrol tingkah laku (penerapan aturan dan disiplin pada anak) dan kontrol psikologis (kontrol orang tua terhadap emosi dan perilaku anak) (Zerra-Nezhad, et al, 2015).

\section{SIMPULAN}

Tidak ada hubungan antara pola asuh dengan kondisi sosioemosional anak tuna rungu usia sekolah. Perkembangan sosioemosional anak tuna rungu usia sekolah masih banyak yang belum sesuai dengan perkembangan yang normal maka pihak orang tua dan sekolah lebih memperhatikan lagi perkembangan sosioemosional anak.

\section{SARAN}

Pihak orang tua dan sekolah diharapkan lebih memberikan stimulus untuk meningkatkan perkembangan sosioemosional anak tunarungu.

\section{DAFTAR PUSTAKA}

Antonopoulou, et al. 2012. Parenting Style of Mothers with Deaf or Hard-of-Hearing. Children and Hearing Sibling. Journal of Deaf Studies and Deaf Education. doi:10:1093/deafed.

Baumrind, Diana. 2011. Prototypical Description of 3 Parenting Style. http://www.devspy.org/teaching/parent/Ba umrind/parenting style (Diakses pada 10 September 2015).
Berg, Brook. 2011. The effect of parenting styles on a pre school aged child 's social emotional development. a research paper. University of Wisconsin-Stout. http://www2.uwstout.edu/content/lib/thesis /2011/2011bergb.pdf

Edwards, D. 2006. Ketika Anak Sulit Diatur:Panduan Bagi Para Orang Tua untuk Mengubah Masalah Perilaku Anak. Bandung: PT Mizan Pustaka. 
Edwards, Leslie. 2015. Communication Skills for Hearing Impaired People. https://communityfund.aviva.co.uk/voting/project/view/15528

Frick, P.J. 1991. Alabama Parenting Questionnaire (APQ). (http://cyfernetsearch.org/sites/default/files /PsychometricsFiles/ParentingQuestionnair e-Alabama(parentsofchildren6-18)_0.pdf) (Diakses pada 10 Septermber 2015).

Galih, J. 2009. Pengaruh Tingkat Pendidikan Orang Tua Terhadap Pola Asuh Anak pada Masyarakat Desa Campurejo Kecamatan Boja Kabupaten Kendal. http://one.indosripsi.com/judulskripsi/pend idikankewarganegaraan/pengaruh-tingkatpendidikan-orang-tua-terhadap-pola-asuhanak (Diakses pada tanggal 10 September 2015).

Herlina. 2013. Hubungan Pola Asuh Keluarga dengan Kemandirian Anak Usia Sekolah di Cimanggis Kota Depok (Diunduh pada 20 Oktober 2015).

Hintermair, Manfred. 2007. Prevalence of socioemotional problems in deaf and hard of hearing children in Germany. American annals of the Deaf, Volume 152, number 3, Summer 2007, pp.320-330.
Kemenkes. 2010. Pedoman Pelayanan Kesehatan Anak di Sekolah Luar Biasa bagi Petugas Kesehatan. Jakarta: Kemenkes.

Poulou, Maria S. 2010. The Role of Trait Emotional Intelligence and Social and Emotional Skills in Students' Emotional and Behavioural Strengths and Difficulties: A Study of Greek Adolescents' Perceptions. Greece: University of Partas. www.enseceurope.org/journal (Diakses pada 10 September 2016).

Rahmanpour, et al. 2014. Comparing Parenting Styles of Parent of Hearing-Impaired Children and Parent of Normal Children. International Journal of research Technology Management. Vol. X.

Smart, Aqila. 2014. Anak Cacat Bukan Kiamat: Metode Pembelajaran \& Terapi untuk Anak Berkebutuhan Khusus. Yogyakarta: Katahati.

Summer. 2009. Understanding Social and Emotional Development in Young Children. New York: Mid-State Central Early Childhood Direction Center Bulletin. http://ecdc.syr.edu (Diakses tanggal 05 Februari 2016). 